\title{
多言語多読の意義と可能性:多読実践報告を通じて
}

\section{The Significance and Possibilities of Multilingual Extensive Reading: An Extensive Reading Practice Report}

\section{Rieko Nishigai}

Kokusai Kotoba Gakuin College of Foreign

Languages

\section{Noriko Kobayashi \\ Kokusai Kotoba Gakuin College of Foreign \\ Languages}

Reference Data:

Nishigai, R., \& Kobayashi, N. (2019). 多言語多読の意義と可能性:多読実践報告を通じて [The significance and possibilities of multilingual extensive reading: An extensive reading practice report]. In P. Clements, A. Krause, \& P. Bennett (Eds.), Diversity and inclusion. Tokyo: JALT.

従来型の一斉誢解授業のみで個々の読解力を育成することには限界があるとして、近年、多読を授業に取り入れる教育機関 が增えており、英語教育及び日本語教育における央践研究報告も数多くなされている。本稿では外国語専門学校における、レ ベル差のある日本語学習者を対象に行った多沇授業の実践、及び授業外活動として目標言語の異なる学習者を対象として行 つた多読活動を紹介する。両活動後の記述および聞き取り調査の結果から、多読は学習者の自律的な学びを促し、総合的な 言語能力を高める上で教育的な効果が高いと判断した。また、授業外活動で中国語、韓国語等の多言語による多読を取り入
れた結果、多読は第二言語だけではなく外国語学習においても、同様の効果を期待し得ると結論付けた。さらに、絵本など言 語外の情報から、ことばの背景にある文化への関心を引き出し、多文化理解を促すという相乗効果も期待できると言えよう。

Because reading ability is difficult to teach in a large class, extensive reading (ER) has been incorporated in both English and Japanese classes, and many studies report on ER activities. This report introduces two types of ER activities conducted at a language school: ER as a classroom activity for Japanese (L2) learners with various levels and ER as an extracurricular activity for learners of foreign languages. Postactivity feedback reports indicated that ER activities foster autonomous learning and they are effective in enhancing overall abilities of target languages. Authors also concluded that ER in different languages such as Chinese and Korean, which was done as an extracurricular activity, exerts positive effects not only on L2 learning but also on foreign language learning. In addition, extralinguistic information such as pictures brings out learners' interest in foreign cultures, which encourages their multicultural understanding.

従来型の一斉読解授業のみで個々の読解力を育成することには限界があるとして、近年、多読 を授業に取り入れる教育機関が増えている。多読の裾野は広がりつつあり、英語教育及び日本語 教育における実践研究報告も数多くなされるようになってきた。川崎(2017) は、大学の教育学部教 養課程の一年生に対し、半年間の英語多読を実践し終了後に行ったアンケート調査の結果から、大 多数の学生が英文を読む速度が上がり、英語に触れる機会が増えたと報告している。その一方で、 母語での読書が苦手な学生は多読に対し悲観的になりがちであるため、多読は万人に有効だとは いえないものの実施する意味は大いにあるとしている。母語による読書経験がそしい学習者は、読 書を習慣化するところから始める必要がある。

読書への関心を引き出し、仲間とともに多読に取り組む時間と空間を作りだすために、教育機関 は読書環境を整備し、読書する時間を確保していくべきであろう。本稿では、外国語専門学校にお けるレベルの異なる学習者を対象に行った日本語多読授業、並びに課外活動として行った多言語 多読の実践報告から得られた学習者の気づきを基に、形態のいかんによらず、多言語による多読を 推進する意義とさらなる可能性、および今後の課題について述べる。

\section{背景}

Day\&Bamford(1998)は第二言語学習の一環として多読を紹介し、容易な文章を大量に読むことは 読解力の向上につながるであろうと述べている。日本における多読実践は、1990年に酒井 (2002) 
が電通大で実践した英語多読に始まる。100万語多読という明確な目標設定により、新たな学習 法・指導法として認識されるようになり、英語だけではなく日本語学習にも多読が取り入れられるよ うになった(粟野・川本・松田，2012)。近年、多読を授業に取り入れる教育機関も増え、日本語学習 および英語学習における多読の研究事例も増えてきた (粟野他, 2012; 熊田・鈴木, 2015 ; 渡邊・大 場，2016; 高橋, 2016; 川崎,2017他)。とはいえ、日本語教育では、指導者がどのような形態で授業 を運営し、学習者の反応や態度にどのような变化があつたかなど具体的な実践報告はまだ少ない (熊田・鈴木, 2015)。一方英語教育において、渡邊・大場 (2016) は、日本人高校生を対象に実施し た9か月の英語多読の結果から、多くの生徒が多読や英語への興味が高まり、英語を読むことに慣 れ、新しい語彙を学ぶことができたと報告した。

第二言語習得において、目標言語で「読む」作業は重要な技能であるが、「読む」という行為の習 慣化がなされていない学習者も多く、「読む」という行為そのものにも個人差が大きい。だが、個人 のレベルで行われる読書という行為は継続が重要であり、読書習慣のない学習者に対しては、読 書を習慣化させるところから指導する必要がある。日本語教育において、日本で生活する非漢字圈 出身の学習者にとつて、日本語で書かれた文章を読むことに苦痛を感じる学習者が多く存在する。 日本語能力試験N2 (以下N2) 以上に合格しなければ日本での就業や進学は難しいが、多くの場合 基本語彙及び読解能力の低さがブレーキとなっている。クラス内の一斉読解授業では、基礎言語 能力・読解能力に個人差が大きく、共通のテキストを選択することが難しく、基本的な漢字力がな い学習者は「読む」ことに集中できないという問題がある。段階別読み物の多読がその突破口にな るのではないかと思われるが、ただ多読を推奨するだけでは読むようにはならない。熱心に読すの は、もともと読書が好きな学生であることが多く、読書活動が必要な学習者は本を手に取るまでが 第一目標である。また、中上級の学習者の中には、多読は外部試験の読解につながらないという不 満もあり、かつ個人レベルで行われる読書活動に対し代価を払うことに抵抗のある学習者の存在も 多読を授業に取り入れる上での障壁となっている。

授業内多読活動に対して消極的な意見を見聞する一方、実施する形態から多読活動を考察す る見方もある。高橋(2016) は、多読の実施形態を実施環境の違いや学習者の自律性を考慮し、形 態に基づいて整理している。すなわち、(1)「授業内多読活動」(2)教師やファシリテーターの支援を受 けて行われる「授業外多読活動」(3)学習者主導で行われる「自律的教室外多読」の3つである。いか なる学習も個人が自律的に学びを継続することが望ましいが、(2)は(1)に比べて自律性が高く、(3)へ 移行する可能性を持っており、多読活動の継続には教師の支援はもとより、学習者の自律性が大き く影響するという。

本稿で扱う実施形態は(1)と(2)であるが、1)は日本語多読活動であり、(2)は言語を特定しない複 数の言語による多言語多読である。その背景には、グローバル化に伴う学習者の多様化があり、教 育現場の多国籍化(佐久間, 2015) という現象がある。学習者の言語背景が多様化したことで、個別 言語の多読活動から多読形態にも多様性が生じた。授業外多読における複数の言語を横断しての 多言語多読はそのような現象の中から生じてきたニーズでもある。多読活動を「学習者のクラスや レベルは違っても、その変化の過程には共通する点が多く、学習者が読み手としての自己を確立し ていく変遷の過程である」(熊田・鈴木, 2015) と捉えるならば、形態や言語を越えて共通する变遷過 程があるのではないかと考える。
本実践では授業内多読活動として日本語による多読を、授業外多読活動として、実施校の学習 言語である英語、中国語、韓国語を主とする複数の言語を跨いでの多言語多読活動を試みる。二 種類の多読活動が学習者に及ぼす影響について、以下の研究課題に基づきアンケート調査と記述 および聞き取り調查の分析を行うものとする。

研究課題1，多読そのものが学習者の自律的な学びを促し、総合的な言語能力を高めるのであれ ば、形態の違いはどうあれ複数の言語による多読活動においても、共通した影響が見られるか。

研究課題2. 第二言語および多言語による多読は、絵本など言語外の情報からことばの背景にあ る文化への関心を引き出し、多言語多文化への理解を深めることができるか。

\section{方法}

\section{授業内日本語多読}

\section{参加者}

本実践校には、日本語・英語を履修するコースと、多言語 (日本語・英語・中国語・韓国語)を履修す るコースがある。2018年度の在籍者数は両コース併せて179名である。多言語を履修するコースに は、留学生と日本人学生が混在しており、1・2年生併せて 98 名中 40 名が日本人、58名が留学生であ る。日本語・英語を履修するコースは、日本語教育を履修することができ、81名全員が留学生であ る。授業内日本語多読は、2011年に少人数の日本語取り出しクラスで初めて導入した。次第に通常 の日本語クラスでも多読を実践するようになり、2018年で8回目の実施となった。授業内とはいえ、 組織的なカリキュラム編成上の変更に伴う調整等もあり、実施期間も内容も年度によって微妙に異 なる。短いものは3か月程度で、通年で実施した年度もある。年度別の参加者国別内訳は以下のよ うである。漢字圈の学習者は少なく、ほとんどが非漢字圈の学習者である。

表1.日本語多読活動参加者内訳

\begin{tabular}{|c|c|c|c|c|}
\hline 回 & 年度 & 人数 & 参加者国別人数 & 回数 \\
\hline 1 & 2011 & 3 & 中国1 インド祀1 フイリピン1 & 10 \\
\hline 2 & 2012 & 9 & 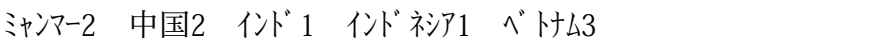 & 10 \\
\hline 3 & 2013 & 9 & ミャンマー3 インド 1 インド祅1 ベト恬 & 20 \\
\hline 4 & 2014 & 10 & ミャンマー6 ベトナム2 中国1 日本1 & 20 \\
\hline 5 & 2015 & 7 & ミャンマ-5 ベトナム1 中国1 日本1 & 30 \\
\hline 6 & 2016 & 16 & ミャンマ-3 ベトナ45 中国2 内モンゴル2 ネパール4 & 20 \\
\hline 7 & 2017 & 16 & 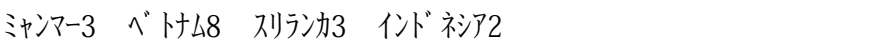 & 10 \\
\hline 8 & 2018 & 39 & ミャンマ-7 ベトナム17 インド祅7 ネパール5 中国1 台湾1则ラ劢 & 10 \\
\hline
\end{tabular}


教材とデー夕収集方法

教材として、『NPO多読読む読む文庫』や『日本語ショートストーリーズ』など主として多読用に書か れた作品を用いた。書庫から教室への移動は籠やワゴンを用いたので、持ち運びしにくい絵本は使 用しなかった。

読書は楽しむためのものであってほしいが、授業の一環として行う以上、成績評価も視座にいれ る必要がある。そのため読書後の課題として読書ノ一ト(付録 1 参照)に本のタイトルとコメントを 記入することを義務付け、達成度を自己管理できるようにした。また、フィードバック記入闌を設け 自己評価を行った。読書ノートへの記入は読書量を可視化することでもあり、モチベーションの維持 につながっている。また修了課題として、自国の民話または文化をテーマにしたバイリンガル絵本の 制作を課した。これらの作品は、新たな学内文庫として活用し、後輩への動機づけとなっている。さ らに実践後に授業の振り返りとしてアンケート調查(付録2参照)を実施し、学習者の多読に対する 意識や受容度を調べることとした。

\section{調查}

日本語多読活動に関する振り返りを行うため、5か月間に渡り授業の開始後30分間多読を行った日 本語学習者を対象に、アンケート調査を実施した(2018年9月実施)。アンケートは5段階のリカート・ スケール（5「強くそう思う」4「そう思う、、「「゙゙ちらとも言えない」，2「あまりそう思わない」１「全く そう思わないり)を用いた。質問項目は、渡邊・大場(2016)をもとに、日本語学習者への質問としてよ り適切な内容となるように一部を変更し、質問7縦書きの文章に慣れてきた」を新たに加え、13項 目とした。実践参加者 39 名から得られた回答のうち、デー夕不備を除いた 34 名(男子 21 名、女子 13 名)を分析対象とした。さらに多読をする前と後とで学習者の読みに対する意識や態度にどのよう な変化が現れたかを、活動中の学習者との対話の中で聞き取りを行った。

\section{授業外多言語多読}

目的

読書習慣を形成するためには授業内多読が効果的であるが、時間数や成績評価などの制約もあ る。より自由な形態で読書の楽しみを味わえる空間と時間が必要であると感じ、2014年には授業外 多読活動としてブッククラブを発足させた。初めは週1回の活動であったが、現在は週2回、各2時間 の活動を行っている。参加は任意であり、3〜7名で活動している。授業内多読は主としてL2の日本 語学習者が中心であったが、課外活動としての多読は国籍・学習言語を問わず、各人が複数の言 語による多読を実践している。授業内多読の目標は何よりも読みを習慣づけることと、多読から新 しい語彙を増やし、さらに文化への関心を引き出すことにあったが、授業外多読では、そ机に加え て授業時間以外の読書環境を提供すること、及び読書を進める上での仲間作りを図ることにより、 外国語学習を継続的に動機づけ、より自律した読み手への成長を目指すものである。

\section{教材と調查}

教材としては、日本語学習者向けには前述の日本語多読シリーズ、英語学習者には英語の Oxford Reading Tree(ORT)シリーズやI Can Readシリーズ、中国語学習者には中国語のEasy Chinese
Readingシリーズなどに加え、多数の絵本を使用した。韓国語は多読用の書籍が不十分であったた め、絵本を多く活用した。また、参加者のレベル差に対応するため、多言語で書かれた絵本や宮沢 賢治や村上春樹などの作品を用意した。

多言語多読活動は当初登録制をとっていたが、他の活動との調整がつかず来なくなる者や読む だけの活動に飽きてしまう者などが多発し、登録制に限界を感じたため、現在では自由参加として いる。授業内活動之異なり、課外活動は個人によって活動の回数や時間も違うため、活動内容を表 1 のような数值として表すことは難しい。よって多言語多読活動を半年以上継続した参加者 5 名と の対話や聞き取りに基づき、言語的背景、活動内容、気づきを表5にまとめる。授業内日本語多読 と異なり、活動の自由度を高めるため、読書ノート(付録3参照)への記入は任意とした。

\section{結果}

\section{日本語多読授業}

表2はアンケート調査対象者の国別を、表3はアンケート結果をそれぞれ示している。

表2.アンケート対象者国別人数

\begin{tabular}{cccccc}
\hline 国名 & ベトナム & インドネシア & ミャンマー & ネパール & スリランカ \\
\hline 人数 $($ 人) & 15 & 7 & 7 & 4 & 1 \\
\hline
\end{tabular}

表3. 日本語多読活動に関するアンケート結果 $(N=34)$

\begin{tabular}{|c|c|c|c|}
\hline No. & & $M$ & $S D$ \\
\hline 1 & もともと、読書が好きだった。 & 3.64 & 1.07 \\
\hline 2 & 授業で多読をしてから本をよむのが好きになった。 & 3.82 & 0.94 \\
\hline 3 & 多読の授業は好きだ。 & 3.50 & 0.75 \\
\hline 4 & 新しい語彙をたくさん学ぶことができた。 & 3.91 & 0.79 \\
\hline 5 & 授業で勉強した文法の使い方がわかるようになった。 & 3.74 & 0.83 \\
\hline 6 & 文章を読むのになれてきた。 & 3.72 & 0.86 \\
\hline 7 & 縦書きの文章を読むのになれてきた。 & 3.71 & 0.84 \\
\hline 8 & 文章を読むのが速くなつた。 & 3.50 & 1.05 \\
\hline 9 & 外部試験 (日本語能力試験など)の長文を速く読めるようになつた。 & 3.24 & 0.92 \\
\hline 10 & 外部試験 (日本語能力試験など)の長文を正確に読めるようになった。 & 2.82 & 0.80 \\
\hline 11 & わからない単語があっても、気にしないで読めるようになった。 & 3.53 & 0.99 \\
\hline 12 & これからも多読を続けたい。 & 3.88 & 0.81 \\
\hline
\end{tabular}




\begin{tabular}{llrrr}
\hline No. & & $M$ & $S D$ \\
\hline 13 & 友達や後輩に多読をすすめるつもりだ。 & 3.91 & 0.97 \\
\hline & & 平均 & 3.61 & 0.89 \\
\hline
\end{tabular}

表3のNo.2「授業で多読をしてから本を読すことが好きになった」No.12「これからも多読を続け たい」、No.13「友達や後輩に多読をすすめるつもりだ」の数值が比較的高いことから、実践参加者 は多読活動を概ね好意的に受け止めており、友達や後輩にも多読をすすめたいと考えていること がわかった。さらにNo.4「新しい語彙をたくさん学ぶことができた」No.5「授業で学習した文法の使 い方がわかるようになった」No.6「文章を読むのになれた」No.7「縦書きの文章を読むのになれて きた」から、多読は語彙学習や文法理解に役立ち、多読を行うことで文章を読むことになれたという 実感が得られたことがうかがえる。一方、No.9「外部試験の長文を早く読めるようになつた」、No.10「 外部試験の長文を正確に読めるようになった」の数值が比較的低いことから、外部試験における読 解の精度を向上させるには至っていないと感じていることがわかった。その要因として、5か月という 実践期間は文章を読むのになれさせるためには十分であるが、読解の精度を向上させるには不十 分であったことが考えられる。

表4は日本語多読学習者への聞き取りから得られた学習者の気づきである。日本語のレベルにつ

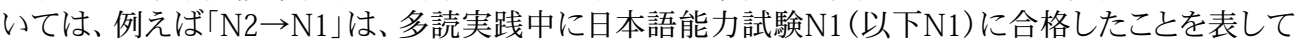
いる。

表4. 日本語多読学習者の声・気づき

\begin{tabular}{|c|c|c|}
\hline 国籍性別 & 日本語レベル & 声•気づき \\
\hline ベトナム(F) & $\mathrm{N} 2 \rightarrow \mathrm{N} 1$ & $\begin{array}{l}\text { N1の読解では、問題を解くために読んでいたけど、今は物語の続 } \\
\text { きが知りたくて読んでいる。 }\end{array}$ \\
\hline 中国(F) & $\mathrm{N} 2 \rightarrow \mathrm{N} 1$ & $\begin{array}{l}\text { 本が好きだから、一人で読めるから楽しい。多読文庫は読めたけ } \\
\text { ご、普通の本は難しい。 }\end{array}$ \\
\hline 中国(F) & $\mathrm{N} 2 \rightarrow \mathrm{N} 1$ & 知らなかったことがいつぱいある。 \\
\hline 箃ラ劢(M) & N1 & この方法は、当たり前で、すばらしいと思う。 \\
\hline 刏ラン力(M) & N3 & 面白い。このtoilet本当にあるの? \\
\hline 祆 $ー ル(F)$ & N2 & このお地蔵さんのお話は私の国にもある。 \\
\hline 祆 $ー ル(M)$ & N2 & 小学生の時読んだ話を日本語で読めて嬉しい。 \\
\hline ミャンマー(M) & $\mathrm{N} 3 \rightarrow \mathrm{N} 2$ & 読めた。もつと読みたい。時間が足りない。 \\
\hline イド祀 $(\mathrm{F})$ & N2 & 縦書きの文に慣れてきた。もつと読みたい。 \\
\hline モコゴル(F) & N2 & 問題集では分からない使い方がよくわかる。覚える。 \\
\hline
\end{tabular}

「縦書きの文に慣れた」「ことばの使い方が分かり覚えやすい」という気づきからは、言語能力の 向上に効果があったという学習者の実感が感じられる。また、トイレや傘地蔵の話への興味は文化 への関心を引き出しているといえよう。何よりも、多読によって読解力が上がることを目的としてい たが、多読後は読書そのものを楽しむ姿勢がうかがわれ、読みの質が変化したものと思われる。

\section{授業外多言語多読}

表5は2017年から2018年にかけて行った授業外多言語多読の聞き取り調査の結果である。表中の「 言語背景」は日本で取得した各種検定試験における成績またはレベルを表している。継続的に活 動に参加した5名の言語背景と活動内容および聞き取り調査や読書ノートから得られた気づきを以 下にまとめる。

\section{表5. 活動の概要と聴き取り調査}

\begin{tabular}{llll}
\hline 参加者 & 国籍性別年齢 & 言語背景 & 活動内容・気づき \\
\hline 1 & 日本 $(\mathrm{F})$ & 英:英検2 & ORTレベル 0 〜レベル3まで読了。その後は時々の
\end{tabular}

ORTレベル0〜レベル3まで

19 中:HSK3 関心と動機により、言語を自由に選択し多読を続け

た。「多言語による読書が好きで、言語を比べながら 読むのが面白い」と言う。英語の音読実践。

2 韓国 $(\mathrm{M})$

韓:ハノ検3

韓国(M) 日:N1

母語での読書経験も豊富で、日本語は超級。日本語 英:TOEIC834 と母語を併せて読むことで、相互に語彙が増え、「日 中:HSK3 本語の読解力・表現力が上がった」という。Bookクラ ブで宮沢賢治を手にし、グスコーブドリを翻訳。オノ マトペの翻訳は難しいという。
3 刏ラ劢(F)

日:N2 英:日常会話 程度

4 ミャントー $(\mathrm{F})$

26

5 日本 $(\mathrm{F})$

22
日本語多読を中心に物語を読む。有名な物語(蜘蛛 の糸など)も、簡単な日本語で読めたことがよかつ た。仏教の本もやさしい日本語で読む。日本語の音 読実践。クラブで一生懸命努力する仲間と出逢えた ことが嬉しかった。

日:N 2 日本語多読0レベルから3レベルまで読了。読解が速 英:日常会話くなったという実感がある。村上春樹の短編や吉本 程度代ななを読む。主に日本語作品を読む。音読実践。

日:N4 小学1年まで日本、その後フィリピンで大学まで英語 （英語、フィリ 環境。開始当初は日本語会話は十分ではなかった ピ語のセミリ が、日本語多読0レベルから始め、4レベルへ移行。「 ンガル）授業で学んだ語彙や文型の使い方がよくわかって嬉 しい」という。もともと読書が好きで多読・多聴・音読 を実践。多読により、潜在的に眠っていた日本語が呼 び起こされたようである。イ夕リア語の絵本を読み、 多言語への関心をさらに高める。 
参加者3および4は多読授業と並行して課外活動において多読を行っている日本語学習者であ る。授業内日本語多読では段階別読み物を読んでいたが、授業外多言語多読では生教材へと広が りを見せ、より自律的な読み手へと成長した。また参加者5は、多読文庫を読み進むうちに、日本語 の語彙が増えただけではなく、ことばの使い分けや文法の用法も会得していった。背景には、もと もと読書好きだったことに加え、幼少期を日本で過ごしたことで、日本語の潜在能力が活性化され たのではないかと考えられる。さらには多言語の絵本に触れることで他の言語への関心も示してい る。すべての参加者の気づきから、外国語多読を通じて学習言語の総合的な言語能力を高め、さら に多言語多文化への理解を深めたことがうかがえる。

\section{熱察}

研究課題 1 の「形態の違いはどうあれ複数の言語による多読活動においても、多読は学習者の 自律的な学びを促し総合的な言語能力を高めるといった、共通した影響を与えるか」関して、授 業内日本語多読および授業外多言語多読どちらの活動においても、多読は好意的に受容され、個 々の言語能力を高めるのに有効であると結論付けた。本実践の活動は読書への関心を引き出し、 自律的な読みを促し、結果として語彙力や表現力を伸ばし、社会言語運用力を高めることにつなが った。特に授業外多言語多読では読書ノートへの記入は任意としたが、記入により読書量が可視化 されるため、参加者のほとんどが読書ノートの記入を習慣化していたことは、本活動が自律学習へ の糸口となったことを示唆している。さらに、共に活動する仲間の存在が継続的な多読活動の動機 づけになったこともわかった。

研究課題2に関しては、自由記述や聞き取り調査の結果から、第二言語および多言語による多読 は、言語外の情報からことばの背景にある文化への関心を引き出し、多言語多文化への理解を深 めることができると結論付けた。授業内外のどちらの多読活動においても、実践前は試験で得点す ることが読みの目的であったが、本実践を通して、文章から多面的な情報を引き出す読みへと読み の質的変化が促されたことがわかった。

グローバル化の進行につれて社会の多様化はますます進み、教育現場にも多国籍化という現象 がもたらされている(佐久間, 2015)。多様化する社会にあって、言語教育も多様化していくだろう。 社会の多様化にどう向き合っていくかを考えるとき、複言語力をもつ人材を育成するための言語教 育は重要である。複言語力とは必要に応じて複数の言語を切り替えながら、コミュニケーションをし 続けることのできる言語能力を言う。教育現場での言語教育も個別言語の能力を高めることから、 複言語能力を育てる言語教育へのパラダイムシフトが求められるだろう。多言語による多読はその ための一助となりうる。多読に加えて、多聴や音読の活動を並行して行うことで他の言語能力を引 き上げ、言語コードスイッチの切り替えを活性化させることも期待できるだろう。他者の言語を知り、 他者の文化を受容できる人材を一人でも多く輩出すること、あるいはその萌芽を育てることができ るのであれば、多言語多読の社会的な意義はさらに大きくなる。多言語多読を個々の教育現場の 状況に合わせて応用していくことで、さらなる可能性が広がるだろう。そのためには、現場における 実践事例を1つでも多く情報として報告し、共有していくことが望まれる。

\section{おわりに}

本実践では2種類の多読活動を行い、活動中の記述・聞き取り調査および活動後のアンケート調 査を基に、多読の教育的効果を報告した。前述したように、多読によって読書習慣が形成され、語 彙力が増え、言語運用能力が向上しうると考えられる。しかし、多読は推奨するだけではなかなか 浸透しない。仲間と共に読みのトレーニングを行う場として、適切な読書環境を継続的に提供する ことが教育機関としての今後の課題である。

本報告は学習者へのアンケート、および聞き取り調査や記録ノ一トを基に、形態ごとに多読の効 果を概観するに留まった。多読の効果を客観的に検証するには、参加者の習熟度や読書へのレデ イネスなど個々の要因を考慮する必要があり、今後の課題である。

\section{謝辞}

本稿の執筆にあたり、貴重なご助言を下さった査読委員の先生方および山口大学の尊田望先生 に感謝を申し上げます。

\section{Bio Data}

Rieko Nishigai received her MA in comparative culture from Shizuoka University. She has taught Japanese to foreign students for over 20 years and also Japanese teaching methods to both Japanese and foreign students since 2002. Her interests include Japanese education, teaching foreign language method, plurilingualism, and extensive reading. <cestbaudelaire@yahoo.co.jp>

Noriko Kobayashi received her MA in English education from Shizuoka University. She has taught English to students in various age groups for 15 years. Her interests include EFL curriculum and pedagogy and the effects of multiculturalism in EFL education. $<$ kobakoba1568@yahoo.co.jp>

\section{引用文献}

\section{(日本語)}

粟野真紀子・川本かず子・松田緑 (2012)『日本語教師のための多読授業入門』東京:アスク

川崎睦 (2017)「多読に関する理解と態度についての考察－全学共通教育プログラムにおける多読 指導の位置づけ一」『岐阜大学教育推進・学生支援機構年報』3, 92-104.

熊田道子・鈴木美加 (2015)「日本語教育におけるExtensive reading (多読)の実践」『東京外語大学 留学生日本語教育セン夕一論集』41, 229-243

酒井邦秀(2002)『快読100万語!ペーパーバックへの道』東京:ちくま学芸文庫

佐久間孝正 (2015)『多国籍化する日本の学校』東京:勁草書房. 
高橋亘(2016)「日本語多読研究に向けた基礎研究一多読活動の類型化の試みー」『Language,

Area and Culture Studies』22, 369-386.

渡邊政寿・大場浩正 (2016)「日本人高校生を対象とした英語教室内多読の実践」『中部地区英語教 育学会紀要』45, 235-242

\section{(英文)}

Day, R. R., \& Bamford, J. (1998). Extensive reading in the second language classroom. Cambridge, England: Cambridge University Press.

\section{付表A}

\begin{tabular}{|l|l|l|l|l|}
\hline No. & 日付(Date) & 題名(Title) & レベル & 内容や感想 \\
\hline 1 & & & & \\
\hline 2 & & & & \\
\hline 3 & & & & \\
\hline 4 & & & & \\
\hline 5 & & & & \\
\hline 6 & & & & \\
\hline 7 & & & & \\
\hline 8 & & & & \\
\hline 9 & & & & \\
\hline 10 & & & & \\
\hline
\end{tabular}

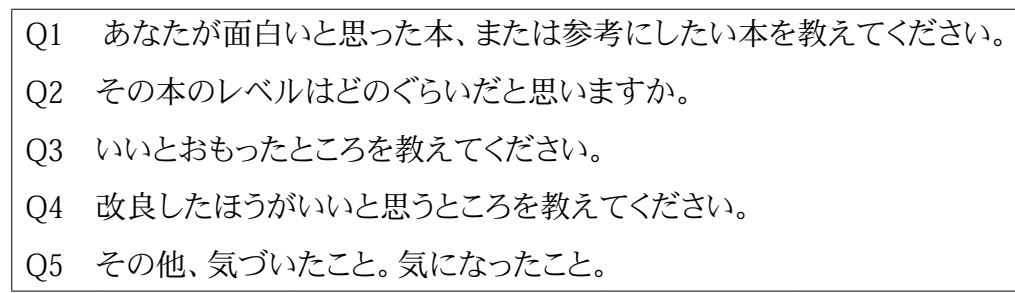

\section{付表B}

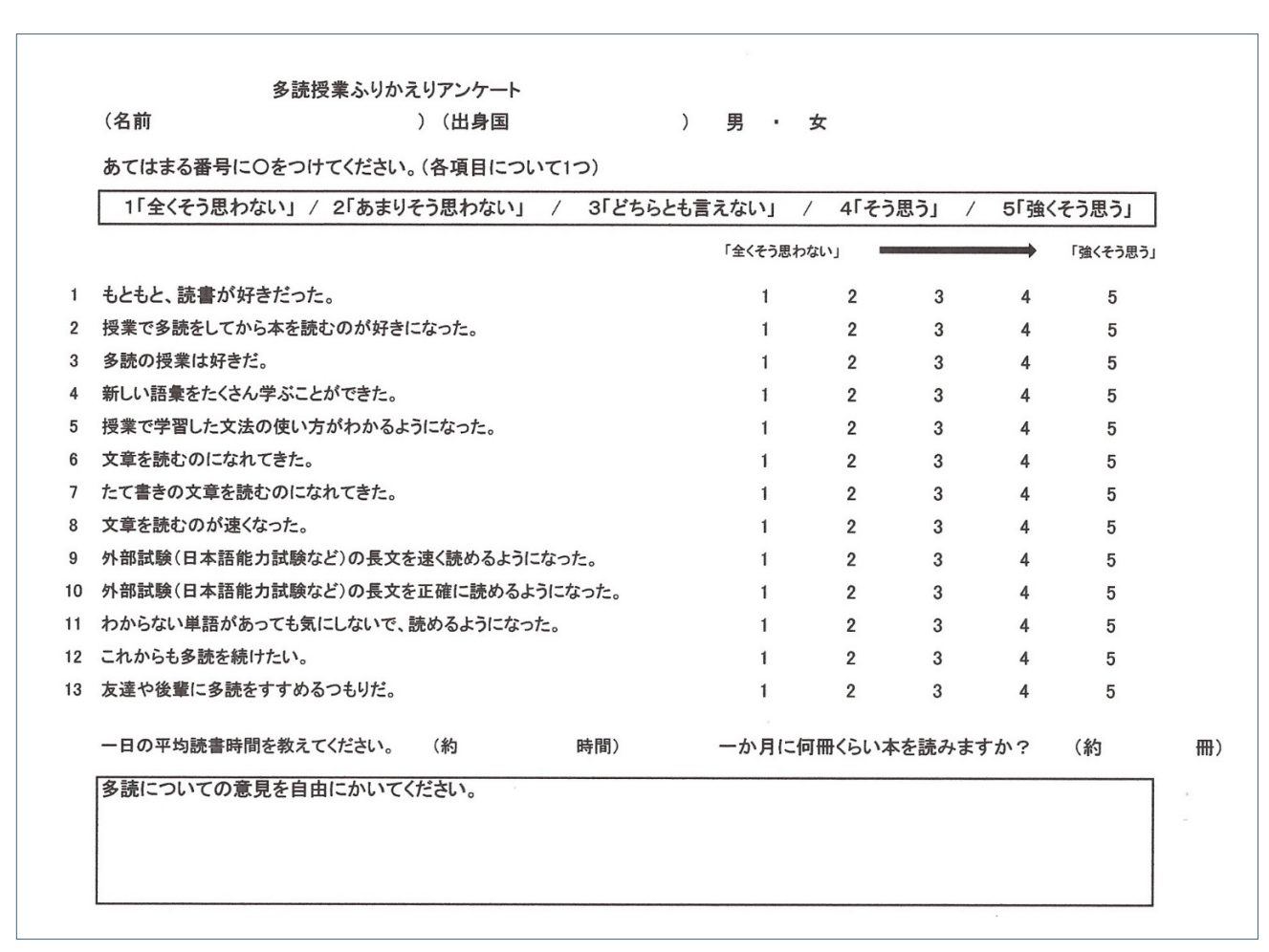




\section{Nu \\ s. \\ \#jalt2018}

JAPAN ASSOCIATION FOR LANGUAGE TEACHING • JALT2018 » Diversity and Inclusion

付表C
\begin{tabular}{|l|l|l|l|}
\hline No & Date(日付) & Title (題名) & Comment (コメント·感想) \\
\hline 1 & & & \\
\hline 2 & & & \\
\hline 3 & & & \\
\hline 4 & & & \\
\hline 5 & & & \\
\hline$<$ Feedback> & & & \\
\hline
\end{tabular}

